\title{
MOUTH FLOOR ENLARGEMENTS RELATED TO THE SUBLINGUAL GLANDS IN EDENTULOUS OR PARTIALLY EDENTULOUS PATIENTS. A MICROSCOPIC STUDY
}

\author{
TUMEFAÇÕES DO SOALHO BUCAL RELACIONADAS ÀS GLÂNDULAS SUBLINGUAIS EM \\ PACIENTES EDÊNTULOS OU PARCIALMENTE EDÊNTULOS. ESTUDO MICROSCÓPICO
}

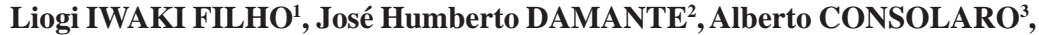 \\ Wellington Cardoso BONACHELA ${ }^{4}$, Carla Andreotti DAMANTE ${ }^{5}$
}

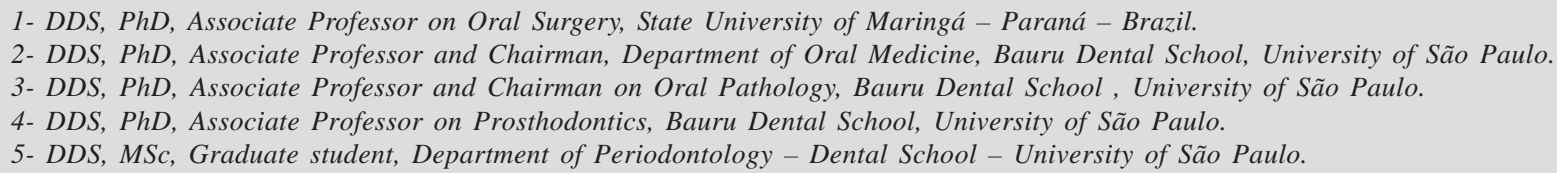

This study was part of the requirements to fulfill the PhD program on Oral Medicine at Bauru Dental School, University of São Paulo and it was supervised by Dr. José Humberto Damante

Corresponding address: Prof. Dr. José Humberto Damante - Al. Dr. Otávio Pinheiro Brisolla 9-75 - Cep.: 17.012-901 - Bauru - São Paulo Brasil - e-mail: damante@fob.usp.br - Fone: (14)32358254

Received: August 22, 2005 - Modification: November 17, 2005 - Accepted: June 20, 2006

\begin{abstract}
$M$

outh floor enlargements (MFE) are observed in edentulous and partially edentulous patients, impairing denture fitting, and have recently been described in the literature as hyperplasias of the sublingual glands. Objective: This study aims at describing the microscopic aspects of MFE that contribute to their final diagnosis. Methods: Twenty-four specimens were surgically removed from the enlarged mouth floor of 19 patients ( 15 females and 4 males). Patient age ranged from 48 to 74 years, with a mean of 57 years. The main surgical indication was to permit or improve the fitting of dentures. Six patients were completely edentulous and 13 were partially edentulous. The material was processed for microscopic examination and stained with hematoxylin-eosin, Mallory's trichrome and periodic-acid Schiff (PAS). Results and Conclusions: The epithelium of the mouth floor was normal in 17 cases, hyperplastic in 4 and atrophic in 3 . Six of the 24 sublingual glands removed were microscopically normal, while the other specimens presented acinar atrophy with hyperplasia of duct-like structures. Interstitial fibrosis was observed in 18 cases and was accompanied by adipose tissue infiltration in 15. Decreased lymphoid tissue was observed in 16 samples and oncocytosis was present in 5 cases. We suggest that MFE in edentulous or partially edentulous patients should be considered as an entity for the text books.

Uniterms: Human salivary glands; Histology; Sublingual gland.
\end{abstract}

\section{RESUMO}

$T$

1 umefações do soalho bucal (TSB) são observadas em pacientes edêntulos ou parcialmente edêntulos, prejudicando a adaptação de próteses, e têm sido descritas recentemente na literatura como hiperplasias das glândulas sublinguais. Objetivo: O objetivo desse estudo é descrever os aspectos microscópicos das TSB a fim de contribuir para o seu diagnóstico final. Material e Métodos: Foram removidos cirurgicamente 24 espécimes de 19 pacientes (15 mulheres e 4 homens) que possuíam TSB. A idade variou de 48 a 74 anos, com média de 57 anos. A principal indicação cirúrgica era permitir ou melhorar a adaptação das próteses. Seis pacientes eram edêntulos e 13, parcialmente edêntulos. O material foi processado para exame microscópico e corado com hematoxilina-eosina, tricrômico de Mallory e ácido periódico de Schiff (PAS). Resultados e Conclusões: O epitélio do soalho bucal estava normal em 17 casos, hiperplásico em 4 e atrófico em 3 . Seis das 24 glândulas sublinguais removidas eram normais microscopicamente, enquanto que as demais apresentaram atrofia acinar com hiperplasia de estruturas ductiformes. Fibrose intersticial foi observada em 18 casos sendo acompanhada por infiltração de tecido adiposo em 15 casos. Uma diminuição no tecido linfóide foi observada em 16 espécimes e oncocitose em 5. Sugerimos que as TSB em pacientes edêntulos e parcialmente edêntulos devem ser classificadas como "entidade” nos livros texto.

Unitermos: Glândulas salivares humanas; Histologia; Glândula sublingual. 


\section{INTRODUCTION}

Enlargement of the major salivary glands is observed in Sjögren's syndrome, alcoholism, amyloidosis, diabetes, sarcoidosis, gout, myxoedema, lymphomas, obesity, and uremia ${ }^{1,2,3}$. Other local diseases such as sialolithiasis, sialoadenitis and benign lymphoepithelial lesions ${ }^{3}$ also cause swelling.

Non-neoplastic enlargements can be observed in the minor salivary glands, especially in the palate. These enlargements are asymptomatic and are microscopically characterized by proliferation of mucosal glandular tissue $^{4,5,6,7}$. They have been called adenomatoid hyperplasia of the mucous salivary glands ${ }^{4}$. The same type of proliferation occurring in serous acini of the sublingual gland has been denominated adenomatoid serous hyperplasia of the sublingual gland ${ }^{3}$.

Asymptomatic mouth floor enlargements (MFE) have been observed in edentulous and partially edentulous patients $s^{8,9,10}$ and may cause difficulties in the fitting of dentures. ${ }^{11,12}$ These swellings are masses that protrude from the mouth floor, are soft upon palpation, and are covered by a normal appearing mucosa. They are asymptomatic and the patient is unaware of the time of evolution ${ }^{8,9,10}$. Although some authors consider these enlargements to be normal variations of the mouth floor resulting from bone resorption in the alveolar margin ${ }^{13,14}$, Campos $^{8}$ described these swellings for the first time in 1996 as a pathological entity and denoted them "hyperplasia of the sublingual glands". The microscopic aspects and etiopathogenesis of these enlargements are still not completely understood and they do even not appear as a nosologic entity in current classifications. Some patients with MFE, in addition to difficulties in the fitting of dentures, are susceptible to bite trauma and require surgical treatment ${ }^{9,10}$. This study aims at describing the microscopic aspects of MFE that contribute to their final diagnosis.

\section{MATERIALS AND METHODS}

Twenty-four specimens were obtained from the enlarged

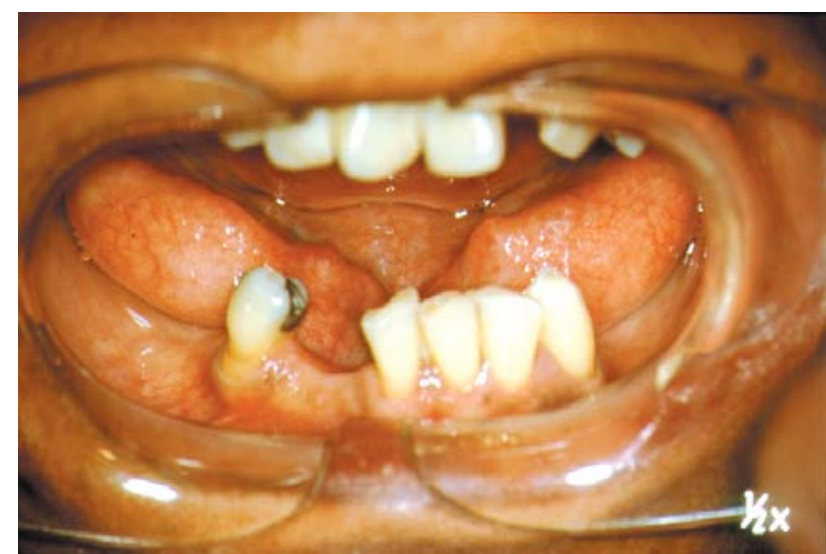

A mouth floor of 19 patients ranging in age from 48 to 74 years (mean of 57 years) between 1985 and 1998. The patients were referred by the prosthodontist to the Department of Stomatology, Bauru Dental School, University of Sao Paulo, due to difficulties in fitting the mandibular dentures. They signed an informed consent form to participate in this study.

MFE included swellings that were soft upon palpation, covered by a normal appearing mucosa and asymptomatic. In some cases the color of the mucosa was yellowish. The swellings were spindle-shaped masses whose size and position changed with the extent of opening of the patient's mouth and tongue movement, and they appeared to be sublingual glands protruding from the mouth floor (Figure 1A).

Analysis of the medical history of patients revealed at least one systemic disease in eight cases: anemia in 1 patient, rheumatism in 1 , liver cirrhosis in 1 , diabetes in 2, and arterial hypertension in 7 . All eight patients had clinically normal parotid and submandibular glands, which were submitted to examination, palpation and milking. Physical aspects of the saliva such as volume, color and fluidity were absolutely normal.

Surgical intervention consisted of two incisions, one medial and one lateral incision, delimiting an ellipse. The specimens containing mucosa of the mouth floor and most part of the sublingual glands were dissected by divulsion. The surgical site was covered with gauze for $24 \mathrm{~h}$ and submitted to healing by second intention to avoid sublingual hematoma and to prevent ranula formation from other minor salivary glands.

All patients were treated with antibiotics, analgesics and non-hormonal anti-inflammatory drugs. Mouthwash containing $50 \% \mathrm{H}_{2} \mathrm{O}_{2}(10 \mathrm{v})$ was prescribed for one week to help in the cleaning of the surgical site. In most cases, postoperative control examinations were carried out after 1 , 3, 7, 15 and 90 days (Figure 1B). After this period, the patients were referred back to the Department of Prosthodontics for prosthetic rehabilitation. All patients signed an informed consent form to participate in the study.

The specimens were fixed in $10 \%$ formalin, processed according to routine procedures, and the slides were stained

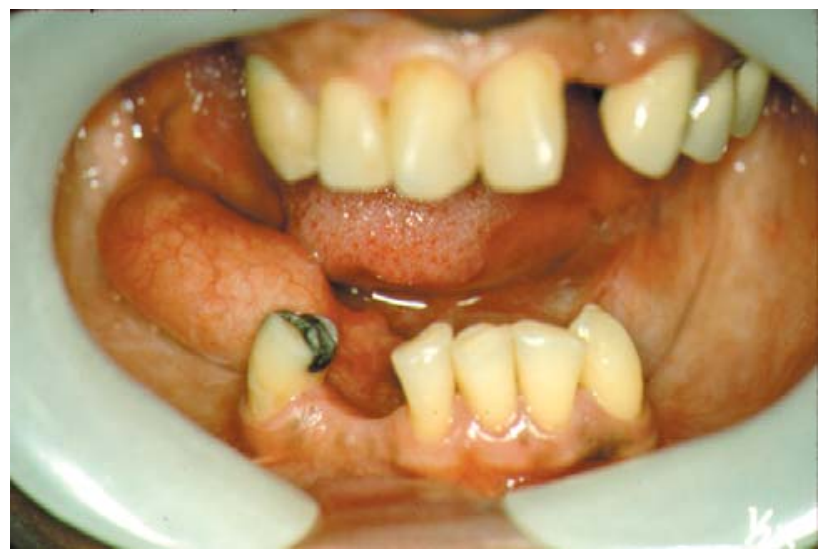

B

FIGURE 1- Mouth floor enlargement in a fifty-eight years old woman. A: Bilateral mouth floor enlargement. B: 15 days postsurgery control (left side) 
with hematoxylin-eosin, Mallory's trichrome and periodicacid Schiff. Microscopic examination was carried out by a single pathologist experienced with the subject. The following microscopic aspects were analyzed: 1) acinar atrophy, 2) hyperplasia of duct-like structures, 3) interstitial fibrosis, 4) increased adipose tissue, 5) decreased lymphoid tissue, 6) retention of intraductal mucus, 7) overflow of mucus to the stroma, 8) inflammatory infiltrate, 9) oncocytosis, 10) epithelial thickening of the oral mucosa, and 11) submucosal characteristics.

Acinar atrophy was classified as discrete (when the number of normal acini exceeded that of atrophic acini), moderate (when the number of normal acini was equal to the number of atrophic acini), or intense (when the number of atrophic acini exceeded that of normal acini). Interstitial fibrosis was classified using the same criteria.

Adipose tissue was only analyzed regarding its presence or absence in both connective tissue septa and parenchyma, but was not quantified. Lymphoid tissue was considered to be normal when aggregated in the periductal or perivascular region, disorganized when undergoing disaggregation, and decreased when the number of mononuclear cells among atrophic acini was smaller than during the disorganization phase upon general observation.

\section{RESULTS}

Of the 19 patients ( 15 males and 4 females), 14 were white and 5 were black. MFE were bilateral in 5 patients and unilateral in 14, with 10 on the right side and 4 on the left.

Microscopically, the swellings were represented by mucosa and submucosa of the mouth floor and by the sublingual gland.

Six of the 24 glands removed were considered to be microscopically normal (Figure 2A) and 18 presented alterations according to the criteria established in the Methods section. The frequency of the microscopic findings observed in the altered glands is shown in Figure 3. All 18 altered glands showed acinar atrophy, which was discrete in 2 cases, moderate in 4 and intense in 12 . The number of ducts and/or duct-like structures was found to be increased in all cases of atrophy (Figure 2B).

Interstitial fibrosis was observed in 17 specimens, being discrete in 3, moderate in 5 and intense in 9 (Figures 2C and 2D).

Infiltration of adipose tissue associated with fibrosis was observed in 15 cases (Figures 2C and 2D). Retention of intraductal mucus was detected in 17 glands (Figure 2B), while none of the specimens showed overflow of mucus to the stroma.

A mononuclear inflammatory infiltrate, although discrete, was noted in 16 cases, while polymorphonuclear cells were absent.

Lymphoid tissue was present in 20 cases, being normal in 4 cases and reduced in 16 (Figures 2E and 2F). Oncocytosis was observed in 5 cases.

The epithelium of the mucosa of the mouth floor was normal in 17, atrophic in 3, and hyperplastic in 9 specimens. The lamina propria was normal in 15 specimens and showed an inflammatory infiltrate in the other nine. The submucosa was normal in 22 specimens. Two of them presented associated fibrosis in the submucosa.

\section{DISCUSSION}

Many dentists consider MFE to be a normal variation in this region, a fact also mentioned in some textbooks ${ }^{13,14}$. However, these swellings impair denture stability ${ }^{11,12}$ and are vulnerable to trauma, sometimes requiring surgical treatment ${ }^{9,10}$. Therefore, knowledge about the microscopic aspects of these enlargements can make an important contribution to the final diagnosis.

What would be the etiopathogenesis of MFE if only some partially edentulous and edentulous patients develop them? If tooth loss would be the only reason, all edentulous patients should show these enlargements. However, our data and those reported by $\mathrm{Campos}^{8}$ demonstrate that previous tooth loss is at least one of the criteria for a patient to develop swellings. In the two series mentioned, all patients were edentulous or partially edentulous.

According to Gershkoff and Goldberg ${ }^{14}$, protrusion of the sublingual glands beyond the alveolar margin is determined by the level of insertion of the mylohyoid muscle. We agree with this observation since mouth floor mobility and the extent of opening of the mouth exacerbate the MFE. However, they are probably not the only factors since many edentulous patients with severe bone resorption in the alveolar margin do not have MFE.

Although eight patients of the present sample had a history of systemic diseases, no clinical alterations were observed in any other major salivary gland, especially the parotid glands which are the main targets of systemic involvement in sialosis and Sjögren's syndrome ${ }^{1,15,16}$. In addition, no specific complaint such as xerostomia, xerophthalmia, swelling or pain was reported by the patients. Furthermore, the microscopic picture of these disorders is also different. In sialosis, acinar cell hypertrophy, edema of the supporting interstitial tissue and atrophy of the striated ducts are observed ${ }^{15}$. Sjögren's syndrome is characterized by initial periductal and perivascular lymphocyte infiltration. This infiltrate can spread throughout the gland, forming germinative centers, followed by acinar atrophy, fibrosis, hyalinization and fat infiltration, with replacement of the parenchyma $^{16}$. This final manifestation of Sjögren's syndrome may resemble the microscopic picture of MFE seen in Figures 2C, 2D, and 2E.

The hypothesis regarding a traumatic etiology of MFE is very strong, since in the present study all swellings were observed in edentulous (6 cases) and partially edentulous patients (13 cases). Draining of food during mastication using dentures or the teeth adjacent to edentulous areas could damage the mouth floor, which is not a masticatory mucosa. However, since most edentulous patients do not present MFE, factors other than trauma, which are still 


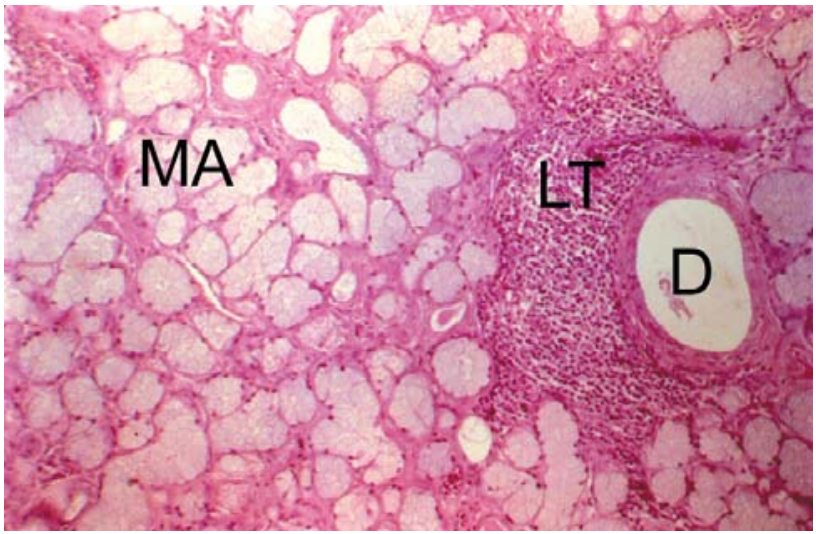

A

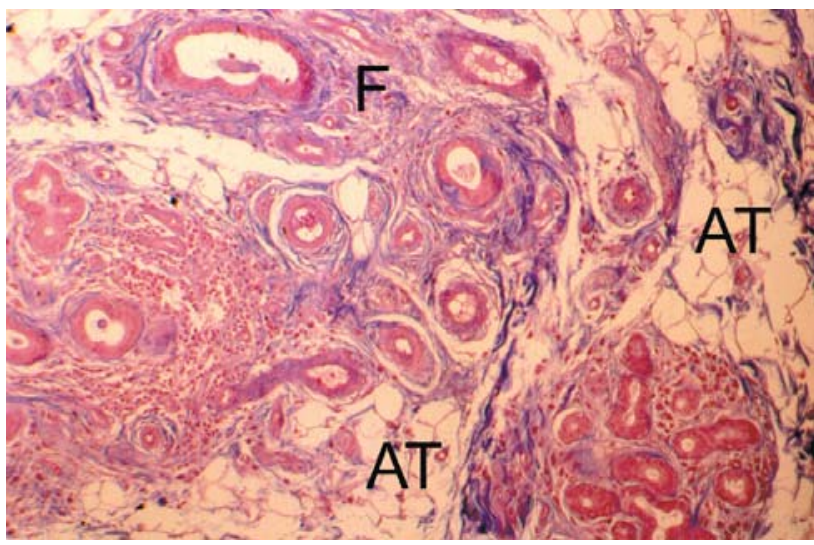

C

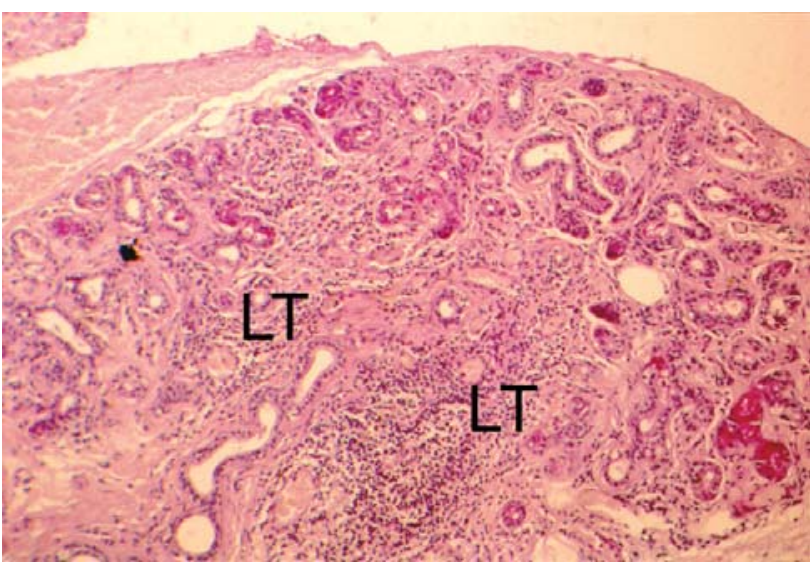

E

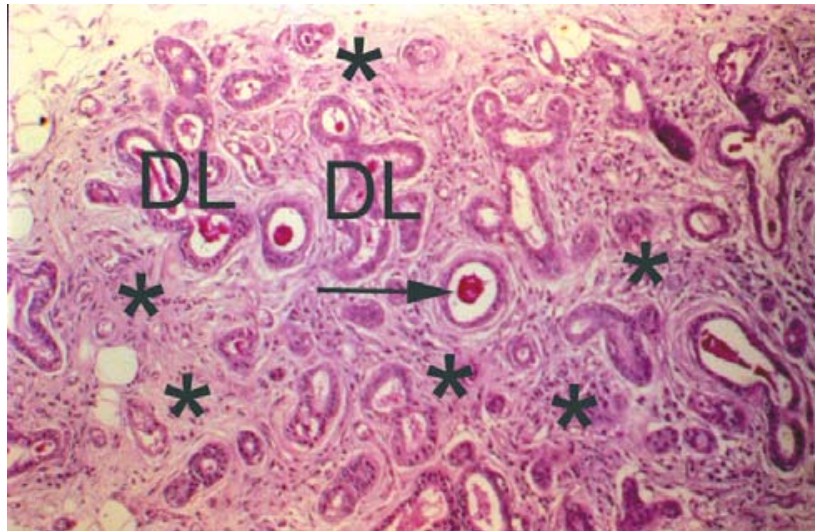

B

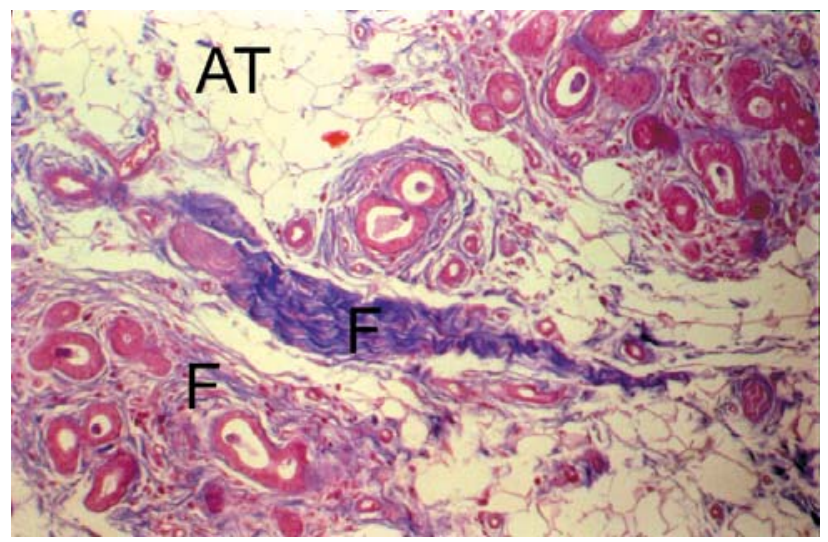

D

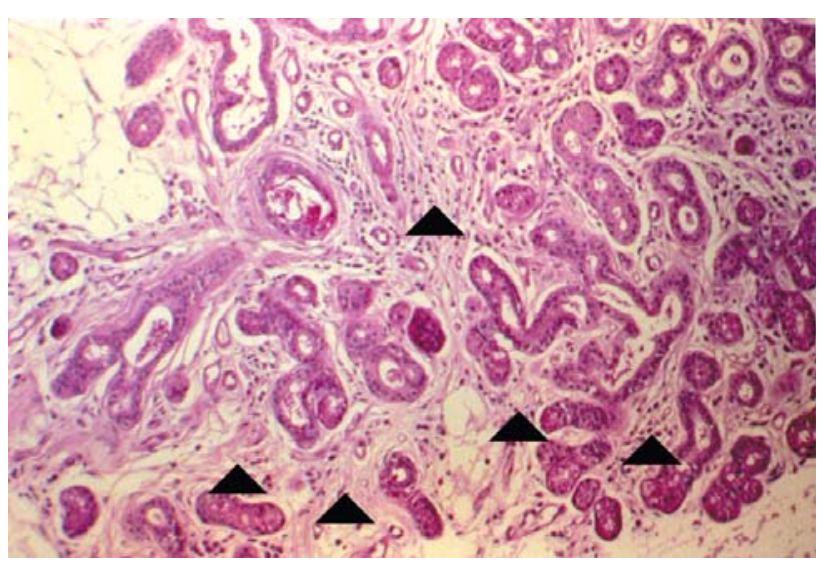

$\mathbf{F}$

FIGURE 2- Main microscopic aspects in the sublingual glands. A: Normal gland with mucous acini (MA) and normal lymphoid tissue (LT) around an excretory duct (D). PAS. Original Magnification - 40X. B: Intense acinar atrophy $\left({ }^{*}\right)$, hyperplasia of duct-like structures (DL) and retention of intraductal mucus $(\rightarrow)$ PAS. Original Magnification - 40x. C: Moderate fibrosis (F) with infiltration of adipose tissue (AT) among duct-like structures. Mallory. Original Magnification - 40x. D: Intense fibrosis (F) and infiltration of adipose tissue (AT). Mallory. Original Magnification - 40x. E: Disorganization and disappearance of lymphoid tissue (LT) among duct-like structures of an atrophic parenchyma. PAS. Original Magnification -16X. F: Disorganization and disappearance of lymphoid tissue ( $\bullet$ ). PAS. Original Magnification - 40x 
unknown, might also be involved. This fact is supported by the present observation that 17 of 24 specimens showed a normal epithelium of the mouth floor, while a hyperplastic epithelium was observed in only 4 cases. The combination of masticatory trauma and the insertion level of the mylohyoid muscle might have been one of the possible causes.

The microscopic aspects of mucocele in minor salivary glands ${ }^{17}$ or of the parotid gland after ligation of the main duct $^{18}$ closely resemble the picture of acinar atrophy observed here. Souza et $\mathrm{al}^{18}$, studying rats submitted to parotid duct ligation and sacrificed after different periods of time, observed acinar atrophy, ductal proliferation accompanied by hyperplasia and dilatation, and interstitial fibrosis, similar to the microscopic findings observed here (Figures 2B, 2C and 2D). Moreover, Oliveira, et al. ${ }^{17}$ also demonstrated the presence of intraductal substance, as observed here in 17 specimens (Figure 2B). In contrast to the study of Souza, et al. ${ }^{18}$ in which glandular volume was unaltered, in the present study the mouth floor was always found to be enlarged (Figure 1A). Normally, obstruction of the excretory duct of a gland leads to enlargement of the organ, which becomes firm upon palpation. In MFE, the mouth floor is enlarged but its consistency is soft. Lymphocytes, the only inflammatory cells observed upon microscopic examination, decrease while acinar atrophy increase (Figures 2E and 2F). Probably, these cells abandon the gland as it loses its function, thus excluding inflammation as a possible cause of the volume increase observed. This mononuclear cells are sometimes difficult to distinguish from others existing in chronic sialodenitis. The diagnosis of MFE depends on the clinical information.

Another possible hypothesis related to the etiopathogenesis of MFE is the aging process. Salivary glands suffer age-related changes such as acinar atrophy, fibrosis, fat infiltration, ductal proliferation and oncocytosis ${ }^{19-25}$. Azevedo, et al. ${ }^{26}$ analyzed age-and-gender related microscopic changes in 186 sublingual glands

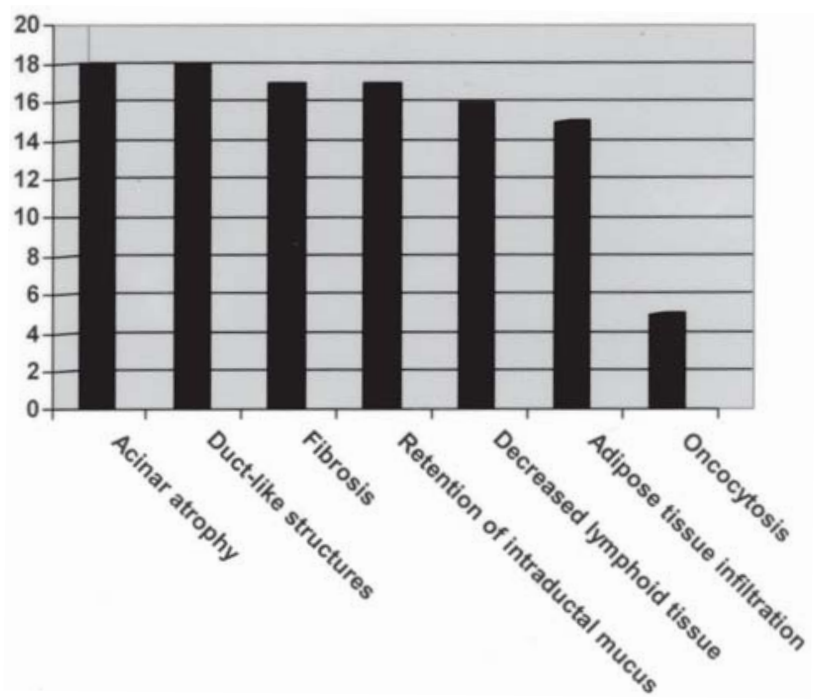

obtained from human cadavers. The study showed that the aging process starts with acinar atrophy, followed by the presence of duct-like structures and ends with replacement of the parenchyma by fibrous and/or adipose tissue, without differences between man and woman. The mean age of patients in the present study was 57 years, a fact supporting the role of aging as an additional etiologic factor, together with the functional alterations resulting from previous tooth loss. Nevertheless, Moreira ${ }^{27}$ showed a decrease in sublingual gland volume with age of $33.73 \%$ in a histomorphometric study of human cadavers. These results discard the aging process hypothesis as one of the etiopathogenesis of MFE. On the other hand, we can speculate that MFE represent an exacerbated elasticity of the mucosa of the mouth floor in some individuals. It would be related to the free tongue movements related to tooth loss and a high insertion of the mylohioide muscle. Maybe MFE are just forms of functional adaptation independent of the microscopic aspects.

Finally, MFE might not be the best name for this entity. Hyperplasia of the sublingual glands ${ }^{8}$ also seems to be inappropriate because this organ is almost always microscopically atrophic. One may call this condition a kind of "atrophic sialadenosis"; however, in the present study six glands showed normal microscopic aspects (Figure. 2A). The same aspects were observed in a study by Campos ${ }^{8}$ where five specimens were microscopically normal. A semiserial study might be useful to demonstrate the onset of atrophy in the organ, although cases showing normal microscopic aspects are known to even further impair hypotheses about the etiopathogenesis of MFE.

\section{CONCLUSION}

New investigations will be necessary to clarify the etiology of MFE that is probably multifactorial. Nevertheless, sufficient information is available indicating that MFE can at least be classified as an "entity" in the text books of Oral Medicine and Oral Pathology.

\section{ACKNOWLEDGEMENTS}

The authors would like to thank Dr. Luciana Reis Azevedo and Dr. Carla Ruffeil Moreira for their contribution to this paper.

\section{REFERENCES}

1- Fulop M. Pouting sublinguals: enlarged salivary glands in myxoedema. Lancet. 1989;2:550-1.

2- Pennec YL, Leroy JP, Jouquan J, Lelong A, Katsikis P, Youinou P. Comparison of labial and sublingual salivary gland biopsies in the diagnosis of Sjögren's syndrome. Ann Rheum Dis. 1990;49:37-9.

FIGURE 3 - Number of microscopic alterations in the affected glands 
3- Tagawa S, Inui M, Mori A, Seki Y, Murata T, Tagawa T. Adenomatoid serous hyperplasia of sublingual gland: a case report. Oral Surg Oral Med Oral Pathol Oral Radiol Endod. 1996;82:437-40.

4- Arafat A, Brannon RB, Ellis GL. Adenomatoid hyperplasia of mucous salivary glands. Oral Surg Oral Med Oral Pathol. 1981;52:51-

5- Buchner A, Merrell PW, Carpenter WM, Leider AS. Adenomatoid hyperplasia of minor salivary glands. Oral Surg Oral Med Oral Pathol. 1991;71:583-7.

6- Devildos LR, Langlais CC. Minor salivary gland lesion presenting clinically as tumor. Oral Surg Oral Med Oral Pathol. 1976;41:657-9.

7- Giansanti JS, Baker GO, Waldron CA. Intraoral, mucinous, minor salivary gland lesions presenting clinically as tumors. Oral Surg Oral Med Oral Pathol. 1971;32:918-22.

8- Campos L. Hyperplasia of the sublingual glands in adult patients. Oral Surg Oral Med Oral Pathol Oral Radiol Endod. 1996;81:584-5.

9- Damante JH, Iwaki Filho L, Consolaro A, Bonachela WC. Floor of the mouth enlargements related to sublingual glands in edentulous or partially edentulous patients [Abstract n.3177]. J Dent Res. 1999; 78(Sp. Issue):503 .

10- Iwaki Filho L. Tumefações do soalho bucal relacionadas às glândulas sublinguais em desdentados parciais e totais. Estudos clínico e microscópico. Bauru [Dissertação (Mestrado) - Faculdade de Odontologia de Bauru - USP, 1999.

11- Grant AA, Johnson W. Removable denture prosthodontics. 2nd ed. London: Churchill Livingstone; 1992.

12- McCord JF, Grant AA. Identification of complete denture problems. A summary. Br Dent J. 2000;189:128-34

13- Castro AL. Estomatologia. 2nd ed. São Paulo: Ed. Santos; 1995.

14- Gershkoff A, Goldberg NI. Dentaduras implantadas. Indicaciones y procedimientos. Buenos Aires: Panamericana; 1961.

15- Mason DK, Chisholm DM. Salivary glands in health and disease. Philadelphia: Saunders; 1975.

16- Cotran RS, Kumar V, Collins T. Robbins pathologic basis of disease. 6th ed. Philadelphia: WB Saunders; 1999.

17- Oliveira DT, Consolaro A, Freitas FJ. Histopathological spectrum of 112 cases of mucocele. Braz Dent J. 1993;4:29-36.

18- Souza LB, Taga EM, Onofre MA, Taga R. Estudo estereológico da atrofia da glândula parótida de rato após ligadura do ducto excretor principal. Rev Odont USP. 1995;9:1-10.

19- Drummond JR, Chisholm DM. A qualitative and quantitative study of the ageing human labial salivary glands. Arch Oral Biol. 1984;29:151-5.

20- Kurashima C, Hirokawa K. Age-related increase of focal lymphocytic infiltration in the human submandibular glands. J Oral Pathol. 1986;15:172-8

21- Scott J. Degenerative changes in the histology of human submandibular salivary gland occurring with age. J Biol Buccale. $1977 ; 5: 311-9$

22- Scott J. Qualitative and quantitative observations on the histology of human labial salivary glands obtained post mortem. J Biol Buccale. 1980;8:187-200.
23- Scott J, Flower EA, Burns J. A quantitative study of histological changes in the human parotid gland occurring with adult age. J Oral Pathol. 1987;16:505-10.

24- Vered M, Buchner A, Haimovici E, Hiss Y, Dayan D. Focal lymphocytic infiltration in aging human palatal salivary glands: a comparative study with labial salivary glands. J Oral Pathol Med. 2001;30:7-11.

25- Waterhouse JP, Chisholm DM, Winter RB, Patel M, Yale RS. Replacement of functional parenchymal cells by fat and connective tissue in human submandibular salivary glands: an age-related change. J Oral Pathol. 1973;2:16-27.

26- Azevedo LR, Damante JH, Lara VS, Lauris JRP. Age-related changes in human sublingual glands: a post mortem study. Arch Oral Biol. 2005;50:565-74

27- Moreira CR. Alterações histológicas da glândula sublingual humana com a idade. Estudo morfométrico. Bauru; 2005. [Dissertação (Mestrado) - Faculdade de Odontologia de Bauru - USP]. 